\title{
Research
}

\section{Evaluating Functional Fit between a Set of Institutions and an Ecosystem}

\author{
$\underline{\text { Julia A. Ekstrom }}^{1,2}$ and Oran R. Young ${ }^{2}$
}

\begin{abstract}
This paper presents a quantitative analytical method for measuring functional fit between a specific ecosystem and a defined set of institutions. Functional misfits, the focus of this paper, can arise as a result of gaps in governance - a lack of institutional provision for a socioecological system component or link. The method measures such misfit using a similarity metric (simple matching). This provides an indication of the potential degree of system-wide fit between an ecosystem and a relevant set of institutions. A preliminary form of the approach uses the text of ocean and coastal laws and regulations to represent formal institutional arrangements. This basic demonstration helps show the complex interrelationships that have to be taken into account in a systematic evaluation of fit. Beyond the first iteration, work continues on developing the analytical capacity of the framework and, therefore, its utility to assist, for example, in policy transitions, including those to ecosystem-based management.
\end{abstract}

Key Words: ecosystem-based management,; governance; institutions; marine policy; problem of fit; socioecological systems

\section{INTRODUCTION}

\section{The Problem of Fit}

This paper presents an analytical technique to help quantify the degree of functional fit between a set of institutions and an ecosystem of interest. "Institutions" as sets of rights, rules, and decisionmaking procedures form a fundamental part of environmental management (Young 1999). How well environmental institutions match spatial or temporal scales of ecosystems and account for functional ecosystem processes is termed the "problem of fit" (Galaz et al. 2008). Functional misfit, the focus of this paper, has contributed substantially to the deterioration of ecosystem services (Young 2002a, b). It concerns the failure of an institution or a set of institutions to take adequately into account the nature, functionality, and dynamics of the specific ecosystem it influences (Costanza and Folke 1996, Young 2002a, Brown 2003, Folke et al. 2007). Accordingly, "gaps" in governance are encountered as a lack of institutional mechanisms to account for links within and among industry sectors and significant properties of the ecosystem. Institutions that leave such gaps thus do not completely fit the ecosystem that encompasses the resource or activity they are designed to manage (Hoel et al. 2005).

\section{Understanding Misfit in the Context of Ecosystem-Based Management}

The need for institutional fit with ecosystems

Problems stemming from misfit have been gaining policy attention (United States Commission on Ocean Policy (USCOP) 2004, Millennium Ecosystem Assessment 2005, Joint Ocean Commission Initiative (JOCI) and Monterey Bay Aquarium (MBA) 2007). Recognition that gaps and overall institution-ecosystem misfits are major contributors to deteriorating ocean health has helped trigger a movement toward ecosystem-based management (EBM) (McLeod et al. 2005, Barnes and McFadden 2008). Ocean management decisions under marine EBM aim to maintain ecosystem processes, functions, and services, rather than separate marine industry sectors (McLeod et 
al. 2005). In this way, EBM calls for an integrated, cross-sector approach based on the ecological system, societal values, scale, and geographic location of interest (Young et al. 2007).

\section{Analysis of misfit: identifying associated institutional gaps and links}

Implementation of EBM must account for the socioecological relationships within and across the relevant marine sectors (Kennish 1992, Sutinen et al. 2000, Juda and Hennessey 2001, McLeod et al. 2005). Transitions to marine EBM thus have to work from the baseline of extant governance arrangements for coasts and oceans that cover these relationships. This demands thorough knowledge of the institutions in place (Cortner et al. 1998, Imperial 1999, Juda and Hennessey 2001, JOCI and MBA 2007) and identification of where institutional arrangements fail to fit the socioecological systems they are intended to manage. Identifying functional misfit entails, in turn, the critical step of identification of the underlying gaps in governance relating to key elements and links in the system of interest.

Research examining fit typically focuses on an individual institution or set of institutions designed to govern a given ecosystem, species, or other topic of interest (Ebbin 2002, Wilson 2006). A single analysis, however, that incorporates a full suite of institutions relating directly or indirectly to a socioecological system allows the identification of system-wide institutional gaps. The ecosystem links within the scope of any relevant institution also need to be discovered in order to deduce which links are not accounted for. Analysis using a full set of institutions can in this way create a system-wide perspective on how the ecosystem is (and is not) governed.

\section{Finding what does fit}

Bolstering institutional arrangements could facilitate EBM (JOCI and MBA 2007). Analysis that shows an institution already accounting for key ecosystem links could assist EBM efforts as much as identifying institutional gaps. In many cases, EBM programs could coordinate using in-place monitoring systems and governance structures (Sutinen et al. 2000, Juda and Hennessey 2001). In addition, institutions are "sticky," i.e., they demonstrate a strong tendency to persist (Young $2002 \mathrm{~b}$ ). They are also path dependent, tending to continue certain practices arising from reasons that may no longer apply (North 1990, Campbell 2004). Knowledge of institutions that support socioecological systems helps stakeholders, managers, and other EBM participants benefit from stickiness and path dependency rather than fighting them.

Matching the scope and mechanisms of an institution to an ecosystem is an essential step. Mitigation or resolution of a misfit, however, does not translate into a simple solution for governance problems (Young 2002a, Crowder et al. 2006, Galaz et al. 2008). An institution that fits with one ecosystem may not fit well with the properties of another ecosystem. Moreover, even when an institution's scope does encompass all key related ecosystem properties, functions, and processes, perfect fit is not equivalent to EBM. Good institutional-ecosystem functional fit must be coupled with temporal and spatial alignment (Crowder et al. 2006), coordination of overlapping jurisdictions, adaptive capacity (Folke et al. 2005), and other factors that shape institutional performance.

Nevertheless, analysis to measure misfit and identify associated gaps could serve as a useful tool to assist integrated, multi-sector governance. Research confirms the need to incorporate all relevant institutions in such analysis (Galaz et al. 2008). A qualitative case study approach would be difficult and time intensive given the large number of institutions that can be involved in governance related to any given socioecological system. Scholars of environmental institutions have traditionally used qualitative approaches in the form of case studies. Such evaluations provide in-depth evaluations of cases based on observations, interviews, and other qualitative information. A quantitative technique, however, can provide a systematic approach that facilitates objective institutional analyses across space and time (Breitmeier et al. 2006). A quantitative approach could also improve communication between social and natural scientists by expanding their common vocabulary. Perhaps the largest added benefit, though, is the capacity of the analysis to consider multiple regimes simultaneously, producing results that could steer, supplement, and complement qualitative investigations (Ekstrom et al. 2009). 


\section{Method to Identify Gaps and Misfit}

The quantitative analysis presented here uses marine management and ecosystem-based principles to help identify institutional gaps and quantify functional fit from a multi-sector perspective for eventual application to EBM efforts. The method assists in identifying:

- Institutional gaps: links in the target ecosystem that are not accounted for in any institutional arrangement; more gaps create a lower fit (thus a higher degree of misfit)

- Potential institutions-ecosystem fit: links in the target ecosystem accounted for by one or more institutions; the more links accounted for by institutions, the greater the potential for institution-ecosystem fit. (We refer to "potential" fit because several other factors may contribute to the degree of fit between institutions and the ecosystem, such as temporal and spatial dimensions, overlapping jurisdictions, enforcement, and other governance features.)

\section{METHODS}

\section{Conceptual Approach}

The institutions-ecosystem fit analysis begins with an ecosystem modeled to the scale of relevance (e. g., an estuary) within the geographic scope of interest (e.g., the Pacific Northwest of the United States) and including the ecological components and relationships identified in consultation with experts as significant. We then define the set of institutions of interest. This process entails netting all likely institutions currently or historically shown to affect the socioecological system in question. Next, we determine whether the ecosystem links are accounted for in the target set of institutions. Those ecosystem links that are discovered to be absent from the scope of all the relevant institutions are designated as system-wide institutional gaps. It follows that the more gaps in the suite of institutions, the lower the degree of potential fit between the institutional governance and the ecosystem. Results also indicate where institutions likely acknowledge ecosystem links.

\section{Ecosystem Data}

First, a conceptual model of the ecosystem in question provides the management target for fit, and thus for measuring institutional fit. An ecosystem can be represented in various forms and various scales (Huggett 1993), but always includes key components of the system and the relationships connecting these components. Inclusion of components and links will differ by scale and properties of interest (Schultz 1967). In our presentation of the analysis, we employ a simplified representation of several Pacific Northwest estuaries because their management falls within the interest of several sectors (pollution, water quality, living marine resources). The ecosystem model used is purposely simplistic in nature to emphasize the demonstration of the technique rather than the development and description of a complex ecosystem model. The model includes both social and ecological components in line with research that demonstrates the need to expand conceptualization of ecosystems in this way (Janssen et al. 2006). Although it is well established that socioecological systems are characterized by dynamic, complex relationships (Levin 1998), to demonstrate the method in its initial stages, our ecosystem model is presented as a basic network of linked species, habitats, and human-based stressors common to the Pacific Northwest (Fig. 1). The conceptual model can be viewed as (A) a network where lines represent links or (B) as a matrix in which links are number ones in the matrix. Adaptation to investigate multi-dimensional formats of ecosystem models is underway.

The ecosystem model includes links between elements that are relevant to estuarine systems in northern California, Oregon, and Washington, including: Humboldt Bay in California (Humboldt Bay Harbor, Recreation and Conservation District (HBHRCD) 2006); Tillamook, Yaquina, and Coos Bays in Oregon; and Willapa Bay and Grays Harbor in Washington (Huppert et al. 2003, Parrish et al. 2003). The components and links in our example estuary have been described in peer-reviewed literature (Huppert et al. 2003, Parrish et al. 2003, Moore et al. 2004), estuary management plans (HBHRCD 2006), a report from the Pacific Northwest Coastal Ecosystems Regional Study (Litle et al. 2000), and other works (Silliman 1941, Johnson and O'Neil 2001). 
Fig. 1. Ecosystem model demonstrating links between a sample of components that are commonly found in estuarine systems in northern California, Oregon, and Washington. (A) represents the ecosystem model as a network diagram, in which lines represent links and (B) represents the same data as a matrix for quantitative analysis, in which "1"s represent links.

A.

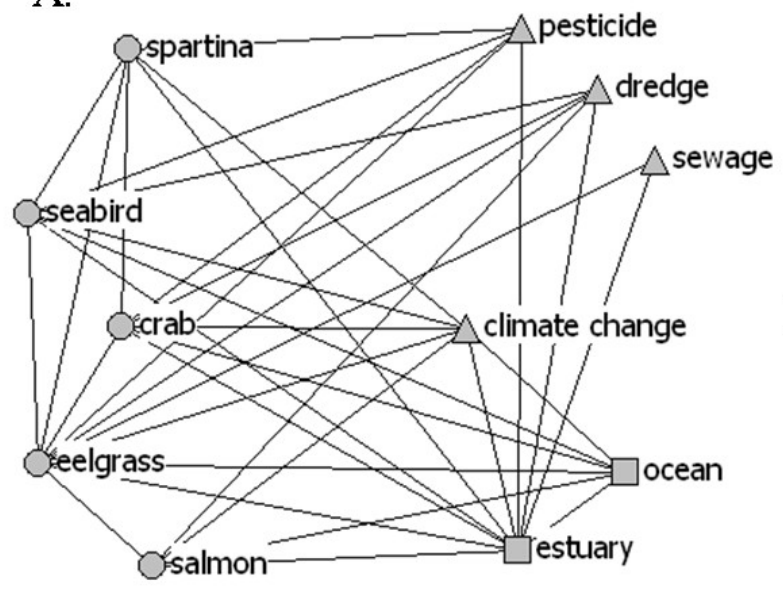

B.

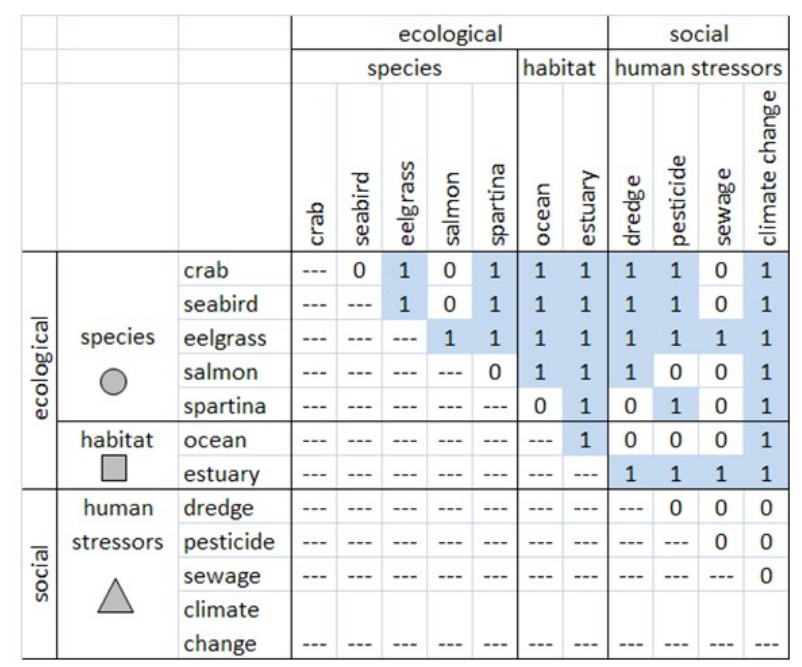

Components are divided into two groupings, the first of which is social and ecological as suggested by Janssen et al. (2006). The second grouping includes three categories: species, habitat, and human stressors. More categories with a more complex representation of an ecosystem, as well as different strengths in links could be incorporated as various values in future applications. Direction of the representation of the links (energy transfer, dependence, and stress) could also be incorporated into analysis.

\section{Institutional Data}

The second data set represents a well-defined set of institutions relevant to the ecosystem modeled. Many types of institutional arrangements shape ocean management, ranging from the formal, such as laws and regulations, to the informal, including social norms and practices established among user groups (North 1990). These could be represented in analysis using data compiled from laws and regulations (as in the analysis presented in this paper), court cases, meeting transcripts, monitoring efforts, government enforcement practices, private foundation and non-governmental organization
(NGO) research, advocacy efforts, and so on. In addition, scholars could use transcriptions of relevant information about management practices gained through semi-structured interviews and other case study methods to generate more complete data for a particular study.

Seeking a capacity to represent multiple scales and multiple sectors of marine management, we used a comprehensive set of ocean-related state and federal laws and regulations that pertains to the west coast of the United States for the year 2006 (Ekstrom and Lau 2008, Ekstrom 2009; data set available at http: //www.cclme.org). Laws and regulations represent de jure institutions in that they are the "rules on paper," which are not necessarily implemented in management practices and procedures. The "rules in use," often referred to as de facto institutions, are those rules, rights, decision-making procedures, and social norms implemented in practice (McCay and Acheson 1987, Ostrom 1990, Hanna et al. 1996). The framework developed in this paper can be used with either de jure or de facto representations of institutions. We use a data set of de jure institutions composed of laws and regulations because these documents are publicly available across all sectors and multiple scales of management (Ekstrom 2009). 
Constraints on using laws in the analysis arise in that they are only the most formal dimensions of institutions and are often outdated. At the same time, these formal rules provide a significant dimension or layer of institutions, especially in the United States, where they are significant drivers and reflections of policy and human interactions with the environment (Kuhl et al. 2007).

Laws and regulations also reflect whether ecosystem relationships have been assigned value by being accounted for in formal governance. Some scholars even suggest that the broad spectrum and detail of legislation related to natural resources in the United States has suppressed the emergence of informal institutional arrangements in natural resource management (Kuhl et al. 2007). Although we do not necessarily subscribe to this perspective, this paper demonstrates the presented institutionecosystem fit analytical framework using a compilation of state and federal laws and regulations (Ekstrom 2009). We recognize legislative objectives do not necessarily translate into goal achievement, and in some cases, agencies do not necessarily implement or enforce their regulations. For example, a species protected under the U.S. Endangered Species Act does not guarantee the maintenance of the species' population (Taylor et al. 2005). As such, taking these data constraints into account, our use of legislation as institutional data to run the fit analysis in fact reveals the "potential" of fit rather than the actual institutionecosystem fit.

\section{Use of text analysis for institutional data}

The method uses laws in a manner different to legal analysis. We employ a type of content analysis, text analysis, which uses terms and phrases to code written material. This facilitates a systematic and repeatable way to answer a variety of questions about the corpus (Weber 1990). Text analysis has proved a useful method in many disciplines, including the social sciences, to quantify various types of relationships within a body of text (Bernard 1998, Baeza-Yates and Ribeiro-Neto 1999, Krippendorff 2004, Lau et al. 2006, Feldman and Sanger 2007). Anthropologists, for example, use text analysis to find occurrences of key terms in order to code and evaluate ethnographic interview transcripts (Bernard 1998). Mass media scholars use term frequency in newspaper texts to understand dissemination and distribution of information (Riffe et al. 2005). Computer scientists explore and develop advanced forms of text analysis, often referred to as information retrieval or text mining (Feldman and Sanger 2007). The applications for text analysis continue to increase as the amount and type of digital data grow (Weber 1990, Krippendorff 2004).

Text analysis can help answer questions about the functional fit of management with an ecosystem because it can quickly reveal whether two concepts are discussed in conjunction with one another. If terms representative of two ecosystem components, such as "dredging" and "eelgrass," co-occur in a single sentence, paragraph, or cohesive unit of text, there is a strong likelihood that the author is acknowledging a relationship between the activity and the species (Weber 1990), if not describing or accounting for the dyad's relationship (e.g., see excerpt below, bold emphasis added)

\section{Washington Administrative Code (WAC) Hydraulic Code Rules}

\section{Dredging in saltwater areas.}

Dredging projects shall incorporate mitigation measures as necessary to achieve no-net-loss of productive capacity of fish and shellfish habitat. The following technical provisions apply to dredging projects. In addition, these projects shall comply with technical provisions and timing restrictions in WAC 220-110-240 through 220-110-271.

(10) Dredging shall avoid adverse impacts to eelgrass (Zostera spp). (Washington State Department of Fish and Wildlife 2006)

Co-occurrence data allow us to organize institutional data in the same format as the ecosystem model using co-occurrence data from each state and federal geopolitical jurisdiction within the geographic scope (California, Oregon, Washington, and federal United States). The cooccurrence tables for laws and regulations, in accordance with the ecosystem model, provide sufficient data to use as a point of departure in determining fit. (Other information about non-legal aspects of institutions can be incorporated in the same way.) 
This institutional analysis based on a socioecological perspective permits the quantification of the degree of fit between an ecosystem and governance that relates to it —or that could or should. The approach can easily be applied to any type of institution beyond laws and regulations to include court cases, transcripts, and even non-text-based information about management. The approach can also be applied to an individual institution or set of institutions representative of a single sector or multiple sectors to help find failure to acknowledge ecosystem links. In addition, the data output provides useful information to explore specific institutional gaps and the degree to which institutions as a whole fit with the ecosystem. Further research can reveal whether institutions can be strengthened and expanded to restore, protect, or mitigate associated impacts to a specific ecosystem link.

\section{Steps to Identify Gaps and Measure Misfit}

The methodology to identify gaps and degree of fit between institutions (represented by legislation) and an ecosystem involves the following steps:

- Identify and model ecosystem of interest (determine components and key links).

- Analyze institutional data, generating a table of how many sections of law and regulation contain co-occurrences of ecosystem components, using the same format as the ecosystem model.

- Identify specific modeled links absent from institution data set (institutional gaps).

- Execute a measure of fit through the comparison of the ecosystem model and institutional data and calculation based on ecosystem links reflected and not reflected in the institutional data.

\section{Co-occurrence of ecosystem term in institutions}

We organized the institutional dimensions of our analysis as a matrix of the same dimensions as the target ecosystem (Fig. 2, Washington example). We employed a Perl code to count the number of sections in which terms co-occurred. Each cell contains the number of sections of law and regulation in which each dyad of terms co-occurs. One law co-occurrence matrix was constructed for each of the following geopolitical jurisdictions: United States Federal, and States of Washington, Oregon, and California. These are "geopolitical" jurisdictions in that they range across two political scales of management (federal and state) and multiple geographic locations (three states along the west coast of the United States).

\section{Identifying Gaps}

If an ecosystem link is not represented in any law (by the co-occurrence method described above), it scores a zero in the law matrix and is considered to be a gap (red lines, Fig. 2A; red cells, Fig. 2B). One institutional gap for Washington, as shown in Fig. 2 , is the relationship between "eelgrass" and "crab." Each gap represents instances where two terms that correspond to different components in a given ecosystem do not occur together in the same section of law for a particular jurisdiction. In addition, we identified region-wide gaps using the sum of all four law matrices. An ecosystem link scoring zero for the sum of the law matrices thus reveals gaps found in all four geopolitical jurisdictions representing $\mathrm{U}$. $\mathrm{S}$. west coast ocean management at two scales of management (federal and state).

\section{Measuring Fit between Institutions and an Ecosystem}

We use a similarity metric to evaluate the degree to which institutions in a given geopolitical jurisdiction potentially account for ecosystem links. We use the simple matching coefficient (M, see equation below), commonly used to measure the similarity between two entities, such as networks, based on presence/absence data (Sokal and Michener 1958, Wasserman and Faust 1994, Hanneman and Riddle 2005). For each geopolitical jurisdiction (California, Oregon, Washington, Federal United States), we calculated the degree of similarity between each law co-occurrence matrix and the ecosystem model. The simple matching coefficient is calculated by the ratio of the sum of modeled links that occur in laws to total number of modeled ecosystem links. This test ignores the instances of co-occurrence in laws of unlinked ecosystem components. A high score of M indicates that a high number of ecosystem links are 
Fig. 2. (A) Network diagram of links that are (solid) and are not (dotted red) accounted for in laws and regulations. (B) Matrix of Washington State laws and regulations co-occurrence data. Each cell contains the number of sections of law and regulation in which each dyad of terms co-occurs. Blue cells indicate relationships modeled for the ecosystem that are accounted for in one or more section of Washington State law and regulation. Red cells with white text indicate modeled relationships in the ecosystem that are not explicitly accounted for in any section of Washington law. Gray diagonal cells with white text contain the number of law and regulation sections in which each individual terms occurs.
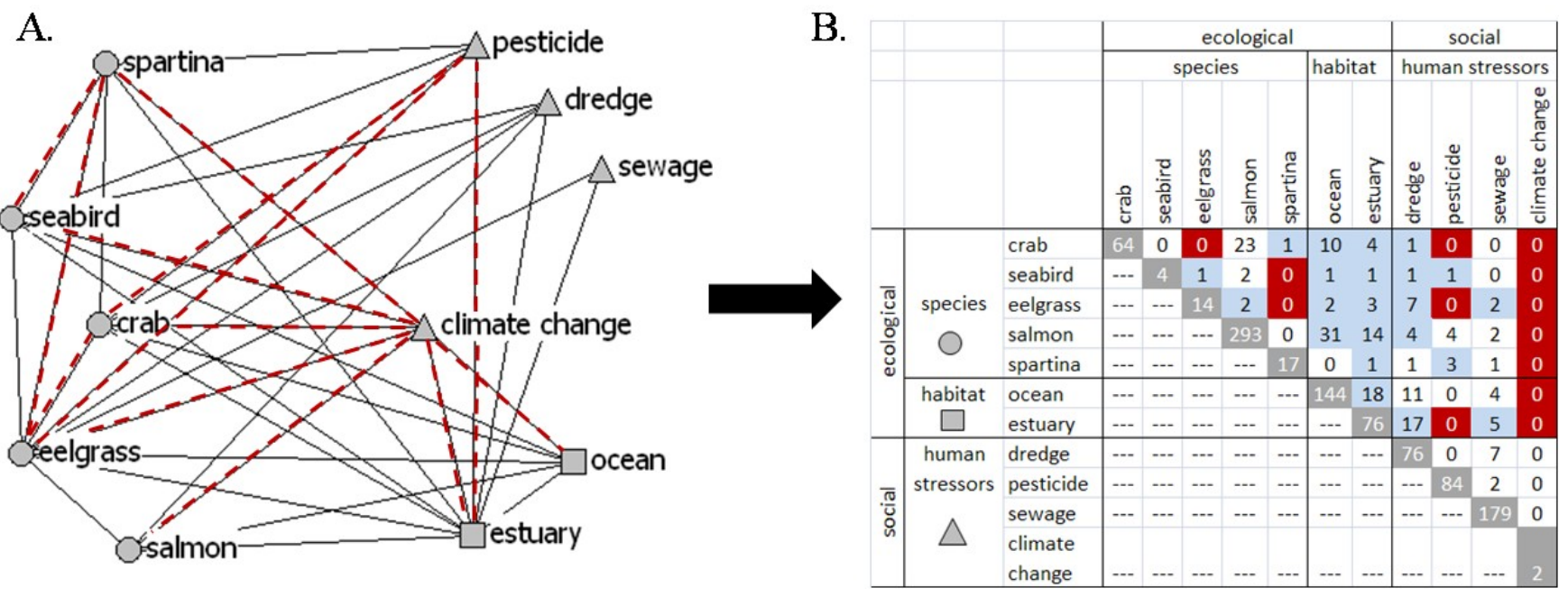

represented in the set of institutions, whereas a lower score indicates a lower fit between the institutions and the conceptually modeled system.

$$
M=\frac{p_{11}}{p_{11}+p_{10}}
$$

Where

p11 is the total number of attributes (cells) that the ecosystem model (Fig. 1B) and the law matrix (Fig. 2B) have with a value $>0$

p10 is the total number of attributes (cells) that the ecosystem model (Fig. 1B) has with a value of 1 and the law matrix (Fig. 2B) has with a value of 0 (Sokal and Michener 1958).

The metric reveals potential fit (rather than certain fit) because the institutional data are derived from text analysis of laws and regulations rather than interpretative, qualitative analysis. In each law matrix, cells with the figure one or higher represent where dyads (two ecosystem components) co-occur in at least one section of law for that geopolitical jurisdiction. For example, Fig. 2A shows that the State of Washington has ten sections of law in which "crab" and "ocean" co-occur.

\section{RESULTS}

Specific institutional gaps emerged and were identified for each geopolitical jurisdiction. Degree of fit varied across geopolitical jurisdictions, with the State of Washington presenting the highest fit with the modeled ecosystem.

\section{Legal Gaps Identified}

Eight ecosystem links were absent universally from laws of all four geopolitical jurisdictions, but ten ecosystem links occurred in all the jurisdictions. In terms of the categories used, five gaps appeared 
between social and ecological components and three among ecological components. Four of the universal gaps related to climate change. Most of the legal gaps present in individual jurisdictions include eelgrass, Spartina, and climate change. Table 1 shows the number of sections (if any) that refer to component dyads in the model for each geopolitical jurisdiction.

\section{Measures of Potential Fit}

A number of links between elements of the ecosystem surfaced in the laws for Washington, Oregon, California, and the United States. The degree of fit among each geopolitical jurisdiction and the ecosystem varied from 0.29 to 0.63 (Fig. 3). Washington laws measured the highest $\mathrm{M}$ (degree of fit) with 13 links left unaccounted for from the ecosystem model's defined links (0.63), seven of which included climate change.

\section{DISCUSSION}

\section{Results Interpretation}

The degree of institutional fit results (M) varied widely across geopolitical jurisdictions. Indicative of sector-based management, no jurisdiction showed a perfect fit (where $M$ would equal 1.0) where every ecosystem link was accounted for in law or regulation. Most gaps were between social and ecological components, which reflects the lack of institutional acknowledgement of humanenvironmental interactions, especially climate change for the year 2006, which these laws represent (Cordell and Bergstrom 1999, Millennium Ecosystem Assessment 2005). See the Appendix for further discussion of specific gaps.

The overall analysis of the degrees of fit shows that the State of Washington's laws explicitly account for more ecosystem links than the other geopolitical jurisdictions investigated for this study. Proportionately, the coast of Washington State contains a higher percentage of estuaries in proportion to open coast than either California or Oregon (Cortright et al. 1987). Therefore, although useful for the purpose of demonstrating the method, a direct comparison of fit across states is not realistic using the same ecosystem model. Rather, alternative ecosystem models will be used that more specifically represent interests, values, and geographies of individual states.

A synthesis of differences in fit among states makes sense in view of the regional histories, issues, priorities, and geographies. The basic demonstration of analysis to reveal gaps and degree of fit also leads to the following questions: (1) what scale of governance is most suited to account for ecosystem relationships? and (2) how should management explicitly account for key relationships in the ecosystem? Information produced through an institutional fit analysis can support further investigation about appropriate (or inappropriate) management scale and institutional design for EBM.

\section{Possible Additional Factors}

Another factor that may contribute to Washington's higher institutional fit with the estuary ecosystem is the progressive steps it has taken toward implementing EBM. Scientists across government agencies and non-governmental organizations have been collaborating to develop ecosystem models for the Puget Sound region, which contains all of the components (and many more) modeled in our demonstration estuarine system (Newton et al. 2000). This modeling and data collection, along with several other efforts over the past several decades, has likely helped in getting the State to account for more of the ecosystem model's links. These efforts have led to a wider collaboration of government agencies, organizations, and other entities that have worked together to form the region's newly established agency, the Puget Sound Partnership, which exhibits the principles of EBM (JOCI and MBA 2007).

\section{Advances in the Technique}

Advanced iterations of the framework can include capacities for enhanced grouping and taxonomic organization of terms to represent components, adjustment of models to be place specific, and verification of results. Furthermore, integrating the institutional fit analysis with the spatial extent of the institutions, such as the data available through the National Oceanic and Atmospheric Administration's Digital Legislative Atlas (Willis 2006, National Oceanic and Atmospheric Administration 2007), 
Table 1. This table presents the dyads of elements in the ecosystem model. Circle symbols $(\bullet)$ indicate relationships that do not co-occur in any section of law (institutional gaps). For example, there is no section of law in the collection containing both the terms "crab" and "eelgrass," which is a link in the ecosystem model.

\begin{tabular}{|c|c|c|c|c|c|c|}
\hline \multirow{3}{*}{ Interaction Type } & & \multirow[b]{3}{*}{ Interaction } & \multicolumn{4}{|c|}{$\begin{array}{l}\text { Number of documents in which } \\
\text { ecosystem dyads co-occur } \\
\text { (by geopolitical jurisdiction) }\end{array}$} \\
\hline & & & USA & WA & OR & $\mathrm{CA}$ \\
\hline & & & & & & \\
\hline \multirow{16}{*}{$\begin{array}{l}\text { Ecological-ecological } \\
\text { interactions }\end{array}$} & Species interactions & Crab-eelgrass & $\bullet$ & $\bullet$ & • & - \\
\hline & & Crab-Spartina & 1 & 1 & - & - \\
\hline & & Seabird-eelgrass & - & 1 & - & 1 \\
\hline & & Seabird-spartina & - & - & - & - \\
\hline & & Eelgrass-salmon & - & 2 & - & - \\
\hline & & Eelgrass-Spartina & • & • & • & - \\
\hline & Species-habitat interactions & Crab-ocean & 11 & 10 & 33 & 8 \\
\hline & & Crab-estuary & 2 & 4 & 6 & 2 \\
\hline & & Seabird-ocean & 3 & 1 & 1 & - \\
\hline & & Seabird-estuary & 1 & 1 & - & - \\
\hline & & Eelgrass-ocean & - & 2 & 1 & - \\
\hline & & Eelgrass-estuary & - & 3 & 2 & - \\
\hline & & Salmon-ocean & 21 & 31 & 66 & 35 \\
\hline & & Salmon-estuary & 8 & 14 & 10 & 8 \\
\hline & & Spartina-estuary & 1 & 1 & • & - \\
\hline & Habitat interaction & Ocean-estuary & 50 & 18 & 31 & 38 \\
\hline \multirow{6}{*}{$\begin{array}{l}\text { Interactions between } \\
\text { social and ecological } \\
\text { aspects }\end{array}$} & $\begin{array}{l}\text { Species-human stressors } \\
\text { interactions }\end{array}$ & Crab-dredge & 3 & 1 & 1 & - \\
\hline & & Crab-pesticide & - & - & 1 & - \\
\hline & & Crab-climate change & • & • & - & • \\
\hline & & Seabird-dredge & 4 & 1 & - & - \\
\hline & & Seabird-pesticide & - & 1 & $\bullet$ & - \\
\hline & & Seabird-climate change & - & • & - & - \\
\hline
\end{tabular}


Habitat-human stressor interactions

\begin{tabular}{|c|c|c|c|c|}
\hline Eelgrass-dredge & - & 7 & - & 1 \\
\hline Eelgrass-pesticide & - & - & - & - \\
\hline Eelgrass-sewage & - & 2 & - & - \\
\hline Eelgrass-climate change & - & - & - & - \\
\hline Salmon-dredge & 5 & 4 & 2 & 2 \\
\hline Salmon-climate change & - & - & - & - \\
\hline Spartina-pesticide & - & 3 & - & - \\
\hline Spartina-climate change & - & - & - & - \\
\hline Ocean-climate change & 1 & - & - & - \\
\hline Estuary-dredge & 17 & 17 & 7 & 12 \\
\hline Estuary-pesticide & 5 & - & 2 & 4 \\
\hline Estuary-sewage & 24 & 5 & 2 & 4 \\
\hline Estuary-climate change & - & - & - & - \\
\hline
\end{tabular}

could provide even more accurate data about extant institutional gaps.

\section{Additional terms}

To cast a wider net than the one thrown using single terms, additional, synonymous groupings, possible also in a taxonomic organization, can represent each ecosystem element (Lau et al. 2006). This can reveal, for example, where a general term, like "invasive species" covers a specific component, such as Spartina. (Alternative terms, however, can be too general: "fish," for instance, may not be sufficiently focused to address a specific link including, say, the component "salmon.") Further analysis can help determine where the ecosystem element is actually addressed and whether an institution needs strengthening in order to address the element.

\section{Adjustment of models}

The strength of links can be incorporated in an ecosystem model (Paine 1980, Granovetter 1983). The degree of fit would then be calculated as the average weighted ratio of institutional links to total ecosystem modeled links. Incorporating different strengths of relationships in ecosystem models would also allow more sophisticated metrics of fit by applying network analysis statistics, such as correlations and network regression tests (Hanneman and Riddle 2005). The more important a link is to the functional integrity and resilience of an ecosystem, the greater the misfit it will create if it is absent from the suite of institutions. A link involving climate change and wetlands, for example, may rank higher in the ecosystem's functional importance than a species-to-species interaction.

An additional advance will use the expertise of ecologists and stakeholders to develop highly accurate ecosystem models that focus on a particular place. Generic models prove useful to illustrate comparisons across jurisdictions, but greater value comes from the application of the framework to specific locations. Ecosystem models could also be used in analysis to help determine degree of institutional preparedness for predicted scenarios, such as climate change impacts and emerging ocean uses and conflicts.

\section{Longitudinal assessment}

With an institutional data set representing a set of institutions over time (using consistent collection criteria), changes in fit could be tracked over time. Reauthorizations and amendments of existing laws, 
Fig. 3. The degree of fit (M) between each geopolitical jurisdiction and the estuarine ecosystem model (between zero and one, where higher is greater fit).

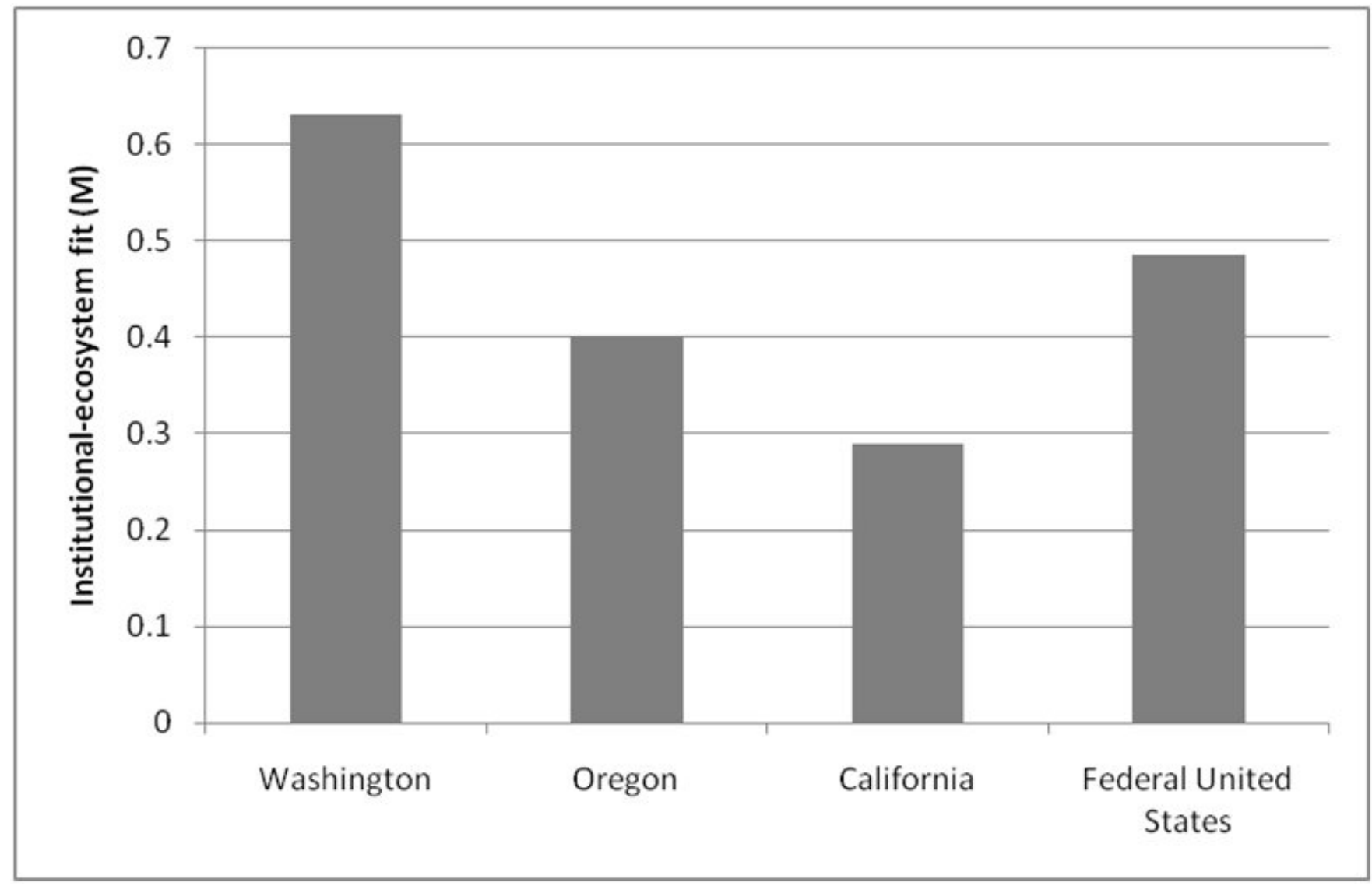

as well as new laws, will likely incorporate language more focused on ecosystem concepts. Such legal developments could be analyzed in conjunction with ecological time series data to evaluate the role of fit in sustaining socioecological resilience. Such longitudinal studies could also serve as performance indicators of institutional dimensions of EBM for monitoring and evaluation efforts.

\section{Verification}

In verifying analysis results, it is necessary to determine what proportion of the co-occurrences include acknowledgment of the ecosystem link; then to see what proportion of those that do can contribute to managing for the relationship. Two additional measures can be deployed to maximize accuracy: (1) gaps can be corroborated by interviews or focus groups with marine ecologists, NGOs, and resource managers; (2) the correlation of location-based results with actual management problems can be confirmed through interviews with and surveys of resource agency representatives, marine scientists, and other stakeholders.

\section{Obstacles}

Full representation of the needs and concerns of diverse stakeholders in EBM programs requires that an institution-ecosystem fit analysis (including, but not limited to functional fit) uses contributions from physical, biological, and social scientists to create conceptual models of socioecological system models based on the best available science. Conceptual models for a particular ecosystem or region, supplied with alternatives, from a diverse 
group of stakeholders would be ideal. However, research to develop models to represent the full suite of socioecological system components and relationships is in its infancy (Janssen et al. 2006).

\section{Opportunities}

The method thus far has used laws and regulations, representing formal institutional governance affecting the components and links of an ecosystem. This affords the advantages of ease of the organization and management of information and of investigation of patterns in the text. Including more facets of management, though, would expand the capacity of the analysis. Additionally, in cases where legislation covers an ecosystem link and the legislation is not implemented in practice, then the analysis would provide a measure of "inactive" institution-ecosystem fit. Incorporating other types of data can provide a more complete representation of institutions to reveal "actual" fit. The analysis can incorporate information from a range of additional formal and informal institutions, such as court cases, stakeholder working-group meeting transcripts, tribal law, management plans, NGO and business policies, and grant agency agendas. Text analysis, or more advanced content analysis, could still be used if such information were in the form of documents; however, if generated consistently, any type of information could be used to determine whether an institution accounts for an ecosystem link. This would also lay the groundwork for examining the disparity between the "rules on paper" and "rules in use" (McCay 2002, Young 2002a) and the connections between formal and informal institutions (Acheson 2003).

Research needs to be conducted on more models to further test the usefulness and interpretability of the technique. Additional models will provide analysis for a variety of ecosystems and scales of biophysical processes and human activities. For example, a system involving seabirds, associated species, upwelling, and other biophysical components could be modeled and tested as a subset of the full ecosystem model simplified for use in this study. Human dimensions and their connections with ecological components must be accounted for in specific place-based models (Ruckelshaus et al. 2008). Data generated from models at different scales could help determine what scale of relationships within an ecosystem are appropriate for optimum management and also which ecosystem relationships are critical across time to sustain system resilience.

\section{CONCLUSION}

The method outlined of institutional fit analysis constitutes a new multi-disciplinary approach to evaluate institutional fit. As such, it can help bring a systems perspective to the evaluation of institutions, a necessary task to achieve EBM with an integrated socioecological standard. This entails crossing traditional sector-specific boundaries and better incorporating ecosystem science with institutional research. In its initial iteration, the analysis of functional fit tests the degree to which links that relate to structural and functional properties of an ecosystem are reflected in the scope of a set of governance arrangements. Quantitative evaluations of functional fit can complement and help direct case studies and qualitative legal analysis; they can also reveal systemic gaps in governance, thus helping to ensure that no socioecological system links are neglected by institutional provisions. Even in its basic form, the method can provide useful baseline information about existing governance in a given region and so assist efforts to transition to EBM. More importantly, as a research tool for exploration of the problem of fit, it holds the potential to increase and further apply our understanding of socioecological systems and the institutional dimensions of environmental change.

Responses to this article can be read online at: http://www.ecologyandsociety.org/voll4/iss2/art16/ responses/

\section{Acknowledgments:}

This research was funded by the University of California Marine Council Coastal Environmental Quality Initiative, California Sea Grant and Ocean Protection Council, the National Center for Ecological Analysis and Synthesis (NCEAS), and the David and Lucile Packard Foundation (Ecosystem-Based Management Tools Initiative Fund). We thank Steve Gaines for discussions in developing the approach to compare ecosystems and governance. We are also grateful to Maria Gordon for her valuable editing contributions and to Sarah Henkel and Elisa Echeverria for comments on early drafts of this work. 


\section{LITERATURE CITED}

Acheson, J. 2003. Capturing the commons: devising institutions to manage the maine lobster industry. University Press of New England, Hanover, New Hampshire, USA.

Baeza-Yates, R., and B. Ribeiro-Neto. 1999. Modern information retrieval. ACM Press, New York, New York, USA.

Barnes, C., and K. W. McFadden. 2008. Marine ecosystem approaches to management: challenges and lessons in the United States. Marine Policy 32:387-392.

Bernard, H. R. 1998. Research methods in anthropology. AltaMira Press, Walnut Creek, California, USA.

Breitmeier, H., O. R. Young, and M. Zürn. 2006. Analyzing international environmental regimes: from case study to database. MIT Press, Cambridge, Massachusetts, USA.

Brown, K. 2003. Integrating conservation and development: a case of institutional misfit. Frontiers in Ecology and the Environment 1 (9):479-487.

Campbell, J. L. 2004. Institutional change and globalization. Princeton University Press, Princeton, New Jersey, USA.

Cordell, H. K., and J. C. Bergstrom, editors. 1999. Integrating social sciences with ecosystem management: human dimensions in assessment, policy, and management. Sagamore Publishing, Champaign, Illinois. USA.

Cortner, H. J., M. G. Wallace, S. Burke, and M. A. Moote. 1998. Institutions matter: the need to address the institutional challenges of ecosystem management. Landscape and Urban Planning 40:159-166.

Cortright, R., J. Weber, and R. Bailey. 1987. The Oregon estuary plan book. Oregon Department of Land Conservation and Development, Salem, Oregon, USA.

Costanza, R., and C. Folke. 1996. The structure and function of ecological systems in relation to property-rights regimes. Pages 13-34 in S. S.
Hanna, C. Folke, and K.-G. Maler, editors. Rights to nature: ecological, economic, cultural, and political principles of institutions for the environment. Island Press, Washington, D.C., USA.

Crowder, L., G. Osherenko, O. Young, S.Airame, E. A. Norse, N. Baron, J. C. Day, F. Douvere, C. N. Ehler, B. S. Halpern, S. J. Langdon, K. L. McLeod, J. C. Ogden, R. E. Peach, A. A. Rosenberg, and J. A. Wilson. 2006. Resolving mismatches in U.S. ocean governance. Science 313:617-618.

Ebbin, S. A. 2002. Enhanced fit through institutional interplay in the Pacific Northwest salmon co-management regime. Marine Policy 26:253-259.

Ekstrom, J. A. 2009. California current large marine ecosystem: publicly available dataset of state and federal laws and regulations. Marine Policy 33:528-531. [online] URL: doi:10.1016/j.m arpol.2008.11.002.

Ekstrom, J. A., and G. T. Lau. 2008. Exploratory text mining of ocean law to measure overlapping agency and jurisdictional authority. Pages 53-62 in M. Charbonneau, L. Diamond, and S. Shulman, chairs. Proceedings of the Digital Government Research Conference. Digital Government Society of North America, Montreal, Canada. [online] URL: http://portal.acm.org/citation.cfm?id=1367844.

Ekstrom, J. A., O. R. Young, S. D. Gaines, M. Gordon, and B. J. McCay. 2009. A tool to navigate overlaps in fragmented ocean governance. Marine Policy 33: 532-535. [online] URL: doi:10.1016/j.m arpol.2008.11.007.

Feldman, R., and J. Sanger. 2007. The text mining handbook: advanced approaches to analyzing unstructured data. Cambridge University Press, Cambridge, UK.

Folke, C., T. Hahn, P. Olsson, and J. Norberg. 2005. Adaptive governance of social-ecological systems. Annual Review of Environment and Resources 30:441-473.

Folke, C., L. Pritchard, F. Berkes, J. Colding, and U. Svedin. 2007. The problem of fit between ecosystems and institutions: ten years later. Ecology and Society 12(1): 30. [online] URL: http://www.e cologyandsociety.org/vol12/iss1/art30/. 
Galaz, V., P. Olsson, T. Hahn, and U. Svedin. 2008. The problem of fit among biophysical systems, environmental and resource regimes, and broader governance systems: insights and emerging challenges. Pages 147-186 in O. R. Young, H. Schroeder, and L. A. King, editors. Institutions and environmental change: principal findings, applications, and research frontiers. MIT Press, Cambridge, Massachusetts, USA.

Granovetter, M.S. 1983. The strength of weak ties: a network theory revisited. Sociological Theory 1:201-233. [online] URL: http://www.si.umich.edu/ rfrost/courses/SI110/readings/In Out and Beyond/ Granovetter.pdf.

Hanna, S. S., C. Folke, and K. G. Maler. 1996. Rights to nature: ecological, economic, cultural, and political principles of institutions for the environment. Island Press, Washington, D.C., USA.

Hanneman, R. A., and M. Riddle. 2005. Introduction to social network methods. University of California, Riverside, Riverside, California, USA.

Hoel, A. H., A. K. Sydnes, and S. A. Ebbin. 2005. Ocean governance and institutional change. Pages 3-16 in S. A. Ebbin, A. H. Hoel, and A. K. Sydnes, editors. A sea change: the exclusive economic zone and governance institutions for living marine resources. Springer, Dordrecht, The Netherlands.

Huggett, R. 1993. Modeling the human impact on nature. Oxford University Press, Oxford, UK.

Humboldt Bay Harbor, Recreation and Conservation District (HBHRCD). 2006. Humboldt Bay management plan: final environmental impact report. HBHRCD, Humboldt Bay, California, USA

Huppert, D., R. L. Johnson, J. Leahy, and K. Bell. 2003. Interactions between human communities and estuaries in the Pacific Northwest: trends and implications for management. Estuaries 26:9941009.

Imperial, M. T. 1999. Institutional analysis and ecosystem-based management: the institutional analysis and development framework. Environmental Management 24:449-465.
Janssen, M. A., O. Bodin, J. M. Anderies, T. Elmqvist, H. Ernstson, R. R. McAllister, P. Olsson, and P. Ryan. 2006. Toward a network perspective of the study of resilience in socialecological systems. Ecology and Society 11(1): 15. [online] URL: http://www.ecologyandsociety.org/vol11/ iss1/art15/.

Johnson, D. H., and T. A. O'Neil, editors. 2001. Wildlife-habitat relationship in Oregon and Washington. Oregon State University Press, Corvallis, Oregon, USA.

Joint Ocean Commission Initiative (JOCI) and Monterey Bay Aquarium (MBA). 2007. Regional ocean governance: an agenda for action. Washington, D.C., USA. [online] URL: http://joint oceancommission.org/resource-center/1-

Reports/2007-08-01 Agenda for Action Regiona 1 Ocean Governance.pdf.

Juda, L., and T. Hennessey. 2001. Governance profiles and the management of the uses of large marine ecosystems. Ocean Development and International Law 32:43-69.

Kennish, M. J. 1992. Ecology of estuaries: anthropogenic effects. CRC Press, Boca Raton, Florida, USA.

Krippendorff, K. 2004. Content analysis. Sage Publications, Thousand Oaks, California, USA.

Kuhl, J.B., S. E. Kraft, and C. L. Lant. 2007. The law and policy of ecosystem services. Island Press, Washington, D.C., USA.

Lau, G. T., K. Law, and G. Wiederhold. 2006. A relatedness analysis of government regulations using domain knowledge and structural organization. Information Retrieval 9:657-680.

Levin, S. A. 1998. Ecosystems and the biosphere as complex adaptive systems. Ecosystems 1:431-436.

Litle, K., S. Breslow, and J. K. Parrish. 2000. Pacific Northwest coastal ecosystems regional study (PNCERS) 2000 report. Submitted to Coastal Ocean Programs, National Oceanic and Atmospheric Administration, Washington, D.C., USA.

McCay, B. J. 2002. Emergence of institutions for the commons: contexts, situations, and events. 
Pages 361-402 in E. Ostrom, T. Dietz, N. Dolsak, P. C. Stern, S. Stonich, and E. U. Weber, editors. The drama of the commons. National Academy Press, Washington, D.C., USA.

McCay. B. J., and J. M. Acheson. 1987. Question of the commons. University of Arizona Press, Tucson, Arizona, USA.

McLeod, K. L., J. Lubchenco, S. R. Palumbi, and A. A. Rosenberg. 2005. Scientific consensus statement on marine ecosystem-based management. Communication Partnership for Science and the Sea (COMPASS). [online] URL: http://compassonline. org/pdf files/EBM Consensus Statement v12.pdf

Millennium Ecosystem Assessment. 2005. Ecosystems and human well-being: synthesis. Island Press, Washington, D.C., USA. [online] URL: http://www.millenniumassessment.org/documents/ document.356.aspx.pdf.

Moore, J. E., M. A. Colwell, R. L. Mathis, and J. M. Black. 2004. Staging of Pacific flyway brant in relation to eelgrass abundance and site isolation, with special consideration of Humboldt Bay, California. Biological Conservation 115:475-486.

National Oceanic and Atmospheric Administration (NOAA). 2007. Digital coast: legislative atlas. NOAA Coastal Services Center, Washington, D.C., USA. [online] URL: http://www.csc.noaa.gov/legis lativeatlas/.

Newton, J., T. Mumford, J. Dohrmann, J. West, R. Llanso, H. Berry, and S. Redman. 2000. A conceptual model for environmental monitoring of a marine system: Puget Sound ambient monitoring program (PSAMP). PSAMP, Washington Department of Fish and Wildlife, Olympia, Washington, USA.

North, D. C. 1990. Institutions, institutional change, and economic performance. Cambridge University Press, New York, New York, USA.

Ostrom, E. 1990. Governing the commons. Cambridge University Press, Cambridge, UK.

Paine, R. T. 1980. Food webs: linkages, interaction strength and community infrastructure. The Journal of Animal Ecology 49:667-685.

Parrish, J., R. Bailey, A. E. Copping, and J. E.
Stein. 2003. The Pacific Northwest coastal ecosystems regional study. Estuaries 26:991-993.

Riffe, D., S. Lacy, and F. G. Fico. 2005. Analyzing media messages: using quantitative content analysis in research. Lawrence Erlbaum, Mahwah, New Jersey, USA.

Ruckelshaus, M. H., T. Klinger, N. Knowlton, D. Demaster, and E. Sala. 2008. Marine ecosystembased management in practice: scientific and governance challenges. BioScience 58:53-63.

Schultz,A. M. 1967. The ecosystem as a conceptual tool in the management of natural resources. Pages 139-161 in ??? Natural resources: quality and quantity. Papers presented before a faculty seminar at the University of California, Berkeley, 19611965. University of California Press, Berkeley, California, USA.

Silliman, R. P. 1941. Fluctuations in the diet of the chinook and silver salmons (Oncorhynchus tschawytscha and O. kisutch) off Washington, as related to the troll catch of salmon. Copeia 1941:8087.

Sokal, R. R., and C. D. Michener. 1958. A statistical method for evaluating systematic relationship. University of Kansas Science Bulletin 38:1409-1438.

Sutinen, J. G., P. Clay, C. L. Dyer, S. F. Edwards, J. Gates, T. A. Grigalunas, T. M. Hennessey, L. Juda, A. W. Kitts, P. N. Logan, J. J. Poggie, B. P. Rountree, S. Steinback, E. M. Thunberg, H. F. Upton, and J. B. Walden. 2000. A framework for monitoring and assessing socioeconomics and governance of large marine ecosystems. NOAA Technical Memorandum NMFS-NE-158. Northeast Fisheries Science Center, Woods Hole, Massachusetts, USA.

Taylor, M. F., K. F. Suckling, J. J. Racklinski. 2005. The effectiveness of the endangered species act: a quantitative analysis, BioScience 55:360-367.

United States Commission on Ocean Policy (USCOP). 2004. An ocean blueprint for the 21st century final report of the U.S. Commission on Ocean Policy. U.S. Commission on Ocean Policy, Washington, D.C., USA. [online] URL: http://www .oceancommission.gov. 
Washington State Department of Fish and Wildlife, editor. 2006. Washington Administrative Code Hydraulic Code Rules. Washington State Department of Fish and Wildlife, Olympia, Washington, USA. [online] URL: http://apps.leg.wa. gov/wac/default.aspx? cite $=220$.

Wasserman, S., and K. Faust. 1994. Social network analysis: methods and applications. Cambridge University Press, Cambridge, UK.

Weber, R. P. 1990. Basic content analysis, Second edition. Sage Publications, Newbury Park, California, USA.

Willis, C. 2006. Digital coast: legislative atlas for the Gulf of Mexico. Paper presented at the 25th Annual International Submerged Lands Management Conference, Redbank, New Jersey, USA.

Wilson, J. A. 2006. Matching social and ecological systems in complex ocean fisheries. Ecology and Society 11(1): 9. [online] http://www.ecologyandso ciety.org/vol11/iss1/art9/.

Young, O. R. 1999. Governance in world affairs. Cornell University Press, Ithaca, New York, USA.

Young, O. R. 2002a. The institutional dimensions of environmental change: fit, interplay, and scale. MIT Press, Cambridge, Massachusetts, USA.

Young, O. R. 2002b. Matching institutions and ecosystems: the problem of fit. Conference donnée dans le cadre du séminaire Économie de l'environnement et du développement durable, coorganisé par l'Iddri et le Medd. Institut du développement durable et des relations internationales, Paris, France.

Young, O. R., G. Osherenko, J. Ekstrom, L. Crowder, J. Ogden, J. Wilson, J. Day, F. Douvere, C. Ehler, K. McLeod, B. Halpern, and R. Peach. 2007. Solving the crisis in ocean governance: placebased management of marine ecosystems. Environment 49:8-19. 


\section{APPENDIX 1. Expanded Discussion of Specific Institutional Gaps}

Several gaps in governance were identified for each jurisdiction. Eelgrass and climate change consistently emerge as components lacking acknowledgement in law and regulation. While 14 sections (four divisions) in Washington law used for this analysis refer to eelgrass, only two sections (derived from the same source document) in Oregon law and one section in California law refer to this component. No reference to the scientific name (Zostera spp.) exists in any law utilized for the analysis. U.S. federal law contains no reference to eelgrass; invariably all eelgrass links in the ecosystem are the subject of gaps at the national level of management. Especially on the federal level, this lack of emphasis on eelgrass may not reveal a problem, but rather this species and its linkages may be covered with broader terms in law, such as through the protection of marine resources in the California Coastal Act and critical habitat under various federal statutes. However, it may be notable that according to ecology literature and management plans that eelgrass has been heavily degraded in the past century as a result of inadequate protection (Short and Neckles 1999, Duffy 2006, Orth et al. 2006).

Beyond the recognition of eelgrass-related linkages in an estuarine system, a number of significant gaps in management emerged. California, Oregon, and the U.S. do not have any section of law referring to both the estuary and seabird components, an omission that ignores the well established dependency of seabirds on estuaries for refuge (Litle et al. 2000, Parrish et al. 2003).

While it is an issue of concern for many managers and scientists, it is not a surprise that no section of the law collection analyzed accounts for the relationships between climate change and seabirds, salmon, and estuaries. Climate change scientifically has received worldwide attention for its predicted and ongoing impacts on ecosystems, however, until recently, the United States government has failed to account for or even to recognize that such a human-driven global trend exists. On one hand, we were surprised to find the absence of explicit reference to a pesticide and estuary linkage in the State of Washington law since this has become a widely accepted relationship in policy. A high number of sections deal explicitly with the two components but separately (pesticide 84, estuary 76). This demonstrates significant management responsibility, indicating that the gap in the form of a lack of legal treatment jointly of pesticide and estuary might be contributing to the environmental degradation of Washington estuaries. On the other hand, federal level law may in fact cover this linkage; indeed seven sections of U.S. federal law contain both components. However, if this linkage were the sole responsibility of national law and federal agencies, then it would not also appear in Oregon and California analysis. Alternatively, the gap may be misleading because synonymous terms representative of the two components were not used in the text analysis. For example, the name of a specific pesticide or the general term pollution could be queried to find if it occurs in any sections of law with the keyword estuary, or a query could be done on like-terms, such as bay, brackish water, inlet, tidal marsh, or river mouth. All these possibilities can be explored using the next iteration of the technique and are presented here to show the range of complexity the method needs to accommodate.

\section{LITERATURE CITED}

Duffy, J. E. 2006. Biodiversity and the functioning of seagrass ecosystems. Marine Ecology Progress Series 311:233-250. [online] URL: http://www.int-res.com/articles/theme/m311 TS.pdf\#page=59.

Litle, K., S. Breslow, and J. K. Parrish. 2000. Pacific Northwest coastal ecosystems regional study (PNCERS) 2000 report. Submitted to Coastal Ocean Programs, NOAA.

Orth, R. J., T. J. B. Carruthers, W. C. Dennison, C. M. Duarte, J. W. Fourqurean, K. L. Heck, A. R. Hughes, G. A. Kendrick, W. J. Kenworthy, S. Olyarnik, F. T. Short, M. Waycott, and S. L. Williams. 2006. A global crisis for seagrass ecosystems. BioScience 56:987-996. [online] URL: http:// www.bioone.org/archive/0006-3568/56/12/pdf/i0006-3568-56-12-987.pdf. 
Parrish, J., R. Bailey, A. E. Copping, and J. E. Stein. 2003. The Pacific Northwest coastal ecosystems regional study. Estuaries 26:991-993.

Short, F. T., and H. A. Neckles. 1999. The effects of global climate change on seagrasses. Aquatic Botany 63:169-196. 